\title{
Terrain subsidence detected by satellite radar scanning of the Copenhagen area, Denmark, and its relation to the tectonic framework
}

\author{
Peter Roll Jakobsen, Urs Wegmuller, Ren Capes and Stig A. Schack Pedersen
}

In the European Union (EU) project Terrafirma, which is supported by the European Space Agency to stimulate the Global Monitoring Environment System, we are using the latest technology to measure terrain motion on the basis of satellite radar data. The technique we employ is known as persistent scatterer interferometry (PSI); in Denmark, it was previously used to map areas of subsidence susceptible to flooding in the Danish part of the Wadden Sea (Vadehavet) area (Pedersen et al. 2011). That study was part of the flooding risk theme under the TerraFirma Extension project. Another coastal protection monitoring activity in the EU seventh framework project SubCoast followed, in which the low-lying south coast of Lolland, prone to flooding, was studied. The Geological Survey of Denmark and Greenland (GEUS) is also involved in the three-year EU collaborative project PanGeo in which GEUS is one of $27 \mathrm{EU}$ national geological surveys. The objective of PanGeo is to provide free and open access to geohazard information in support of the Global Monitoring Environment System. This will be achieved by providing a free, online geohazard information service for the two largest cities in each EU country, i.e. 52 towns throughout Europe with $c .13 \%$ of EU's population.

The Danish cities selected for investigation under Terrafirma are Copenhagen and Aalborg. Capitals have first priority, and Aalborg was chosen because of good satellite data. In this paper, PSI data for Copenhagen are presented together with interpretations of terrain displacement (Fig. 1).

\section{PSI processing of satellite radar data for Copenhagen}

The satellite data covering Copenhagen were obtained from the descending track D480 ERS satellite in the period 1992-2000. The PSI processing was carried out by Gamma Remote Sensing AG, using a method that was carefully qualified and validated in the Terrafirma project (Crosetto et al. 2008). GEUS carried out the analysis using the program ArcGIS, in which geological and topographical data provide the basis for interpretation. Based on the PSI data, nine areas were outlined in which subsidence had occurred over the pe- riod 1992-2000. The areas are between 0.1 and $2.2 \mathrm{~km}^{2}$ and here we present two of them. Apart from those mentioned above, minor subsidence differences of regional extent have been recognised; these are interpreted as tectonic.

The Copenhagen area that was processed has a size of $960 \mathrm{~km}^{2}$ with a reference point at $55.685668^{\circ} \mathrm{N}$, $12.493937^{\circ} \mathrm{E}$. A total of 419660 PSI points were identified, corresponding to 437 points per $\mathrm{km}^{2}$. The majority of the points $(94.5 \%)$ show small rates of vertical motion, i.e. between -1.5 and $+1.5 \mathrm{~mm} /$ year. A small number of points (1.6\%) show subsidence rates of 3.5 to $1.5 \mathrm{~mm} /$ year, and a few $(0.2 \%)$ show subsidence rates of more than $3.5 \mathrm{~mm} /$ year. A few points $(0.4 \%)$ show uplift rates between 1.5 and $3.5 \mathrm{~mm} /$ year; these are regarded as scattered uncertainties in relation to the average annual motion rate of $0.35 \mathrm{~mm} /$

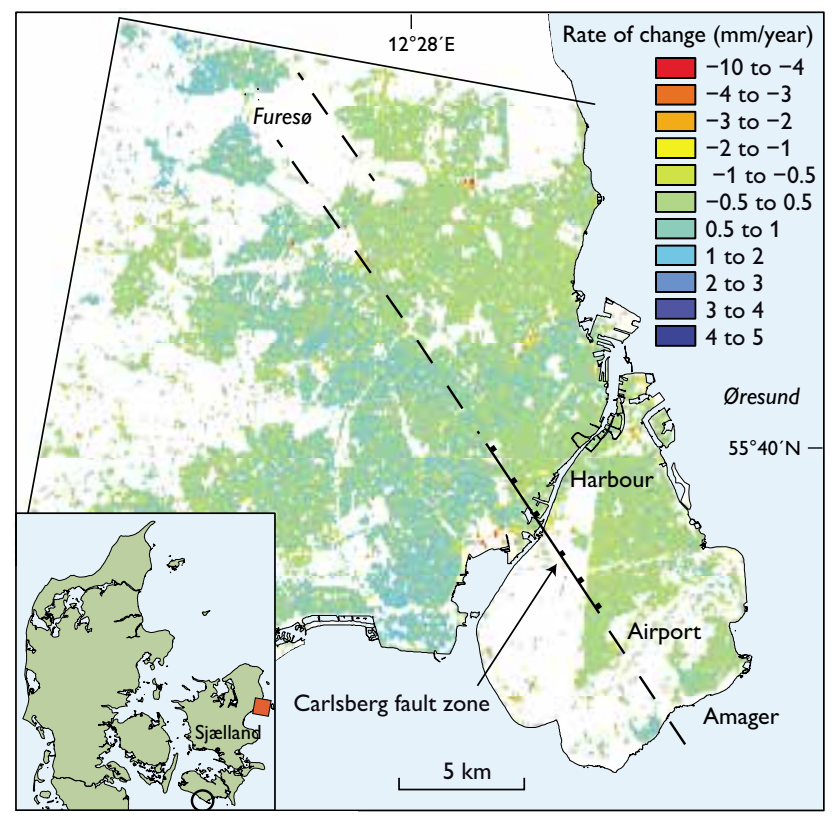

Fig. 1. Map of Greater Copenhagen showing the area covered by PSI data. Vertical movements are represented in a raster grid showing the average movement in $100 \times 100 \mathrm{~m}$ squares. The concentrations of yellow-red colours show areas with maximum rates of subsidence. Note the regional difference in light and dark green colours which might be caused by tectonic subsidence east of the Carlsberg fault zone. 

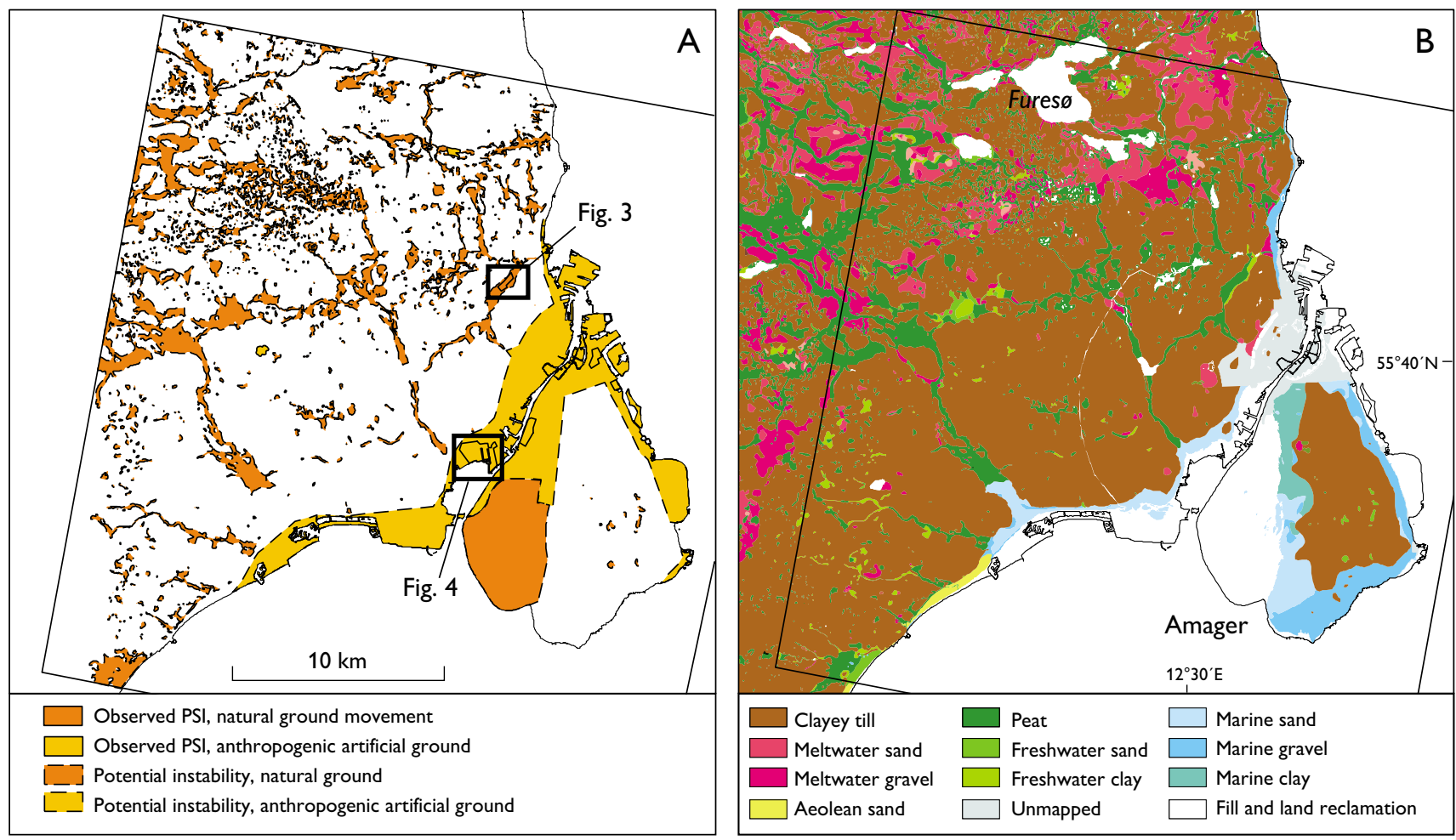

Fig. 2. Correlation between ground stability and surficial deposits in Greater Copenhagen. A: Map of classified soft ground areas in Greater Copenhagen. The rectangles show the location of two examples of subsiding areas described in the text. B: Geological map of surficial deposits. The fill and reclamation areas did not exist when the region was mapped in 1899 (Rørdam 1899).

year for the entire area, with a standard deviation of annual motion rate amounting to $0.74 \mathrm{~mm} /$ year.

\section{The geology of Copenhagen and its relation to subsidence areas}

Copenhagen is located on the east coast of the island of Sjælland, which is separated from Sweden by the strait of Øresund (Fig. 1). Part of the city extends onto the smaller, neighbouring island of Amager, and the strait between the two islands is the site of Copenhagen harbour. The airport of Copenhagen, Kastrup, is situated on the southern part of Amager. Most parts of Copenhagen are lowland, i.e. a few metres above sea level, but the terrain rises northwards and westwards where it reaches heights of $50 \mathrm{~m}$ a.s.l.

The bedrock of Copenhagen is dominated by Danian limestone. Two units are found: the Stevns Klint Formation that comprises bryozoan limestone rich in chert beds (Surlyk et al. 2006) and the København Kalk Formation which is dominated by calcarenitic, calcilutitic limestone with chert beds (Stenestad 1976). An important tectonic feature is the Carlsberg fault zone (Stenestad 1976; Jakobsen et al. 2002) that can be followed from the south coast of Amager northwestwards to Furesø (Figs 1, 2).
The Quaternary deposits of Copenhagen comprise ice age and postglacial deposits. The latter consist of terrestrial sediments that accumulated in streams and bogs, and marine sand and gravel which accumulated along the coasts (Fig. 2B). The ice-age deposits are dominated by a widespread young till unit overlying meltwater sand and gravel, and more local, older till units and meltwater clay. Tunnel valleys, depressions in hummocky moraine and stream valleys form wetlands around Copenhagen, where freshwater deposits, mainly peat, accumulated in the Holocene. The western part of Amager is reclaimed sea floor with marine and coastal deposits. Areas with dump and fill deposits occur along the coasts or in peat-dominated depressions and may be characterised by high rates of subsidence.

\section{Examples of areas with subsidence}

Based on the geology and records of man-made ground, there are three types of areas with potential risk of subsidence, namely areas underlain by postglacial peat deposits (amounting to $\left.70 \mathrm{~km}^{2}\right)$, large areas of man-made ground $\left(53 \mathrm{~km}^{2}\right)$ and small areas of reclaimed land $\left(19.4 \mathrm{~km}^{2}\right)$.

One of the areas with subsidence identified from the PSI data in the period 1992-2000 is Lersøparken (Figs 2, 3) with 

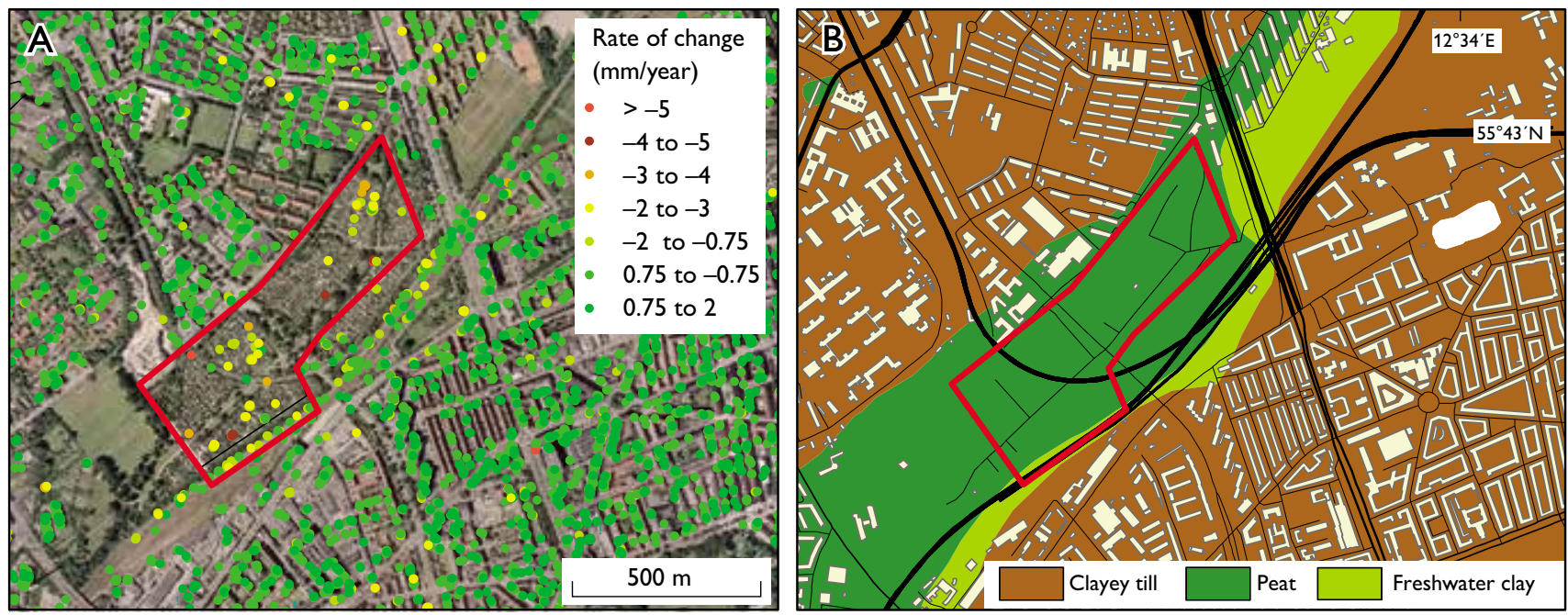

Fig. 3. Detailed map of Lersøparken (red frame). A: Orthophotograph of the area with PSI points representing areas of subsidence. B: Geological map of the area showingt clay and peat in the NE-SW-striking valley. For location see Fig. 2.

a subsidence rate between 2 and $5 \mathrm{~mm} /$ year. The $0.22 \mathrm{~km}^{2}$ subsiding area is situated in a NE-SW-trending valley where postglacial peat has accumulated above clay in an elongated depression (Fig. 3). The depression was used as a dump site in the period from 1880 to 1920 . Peat is easily compressed, and compaction of the waste is an additional factor accounting for the high subsidence rate.

Kalveboderne with Valbyparken and Tippen along the coast of southern Copenhagen is another example of an area with subsidence (Figs 2, 4). A considerable number of PSI points show subsidence of more than $4 \mathrm{~mm} /$ year. This area of $1.4 \mathrm{~km}^{2}$ was used as a dump from 1913 to 1960 when waste was dumped on the beach and in the adjacent shallow sea. In 1961, the area was extended with fill to the present artificial shoreline. Compaction of the soft, natural sediments and waste followed by fill deposits lead to subsidence.

\section{Subsidence related to tectonic features}

The most important tectonic feature in the subsurface of Copenhagen is the SE-NW-striking Carlsberg fault zone (Fig. 1). The fault is part of a number of relay faults related
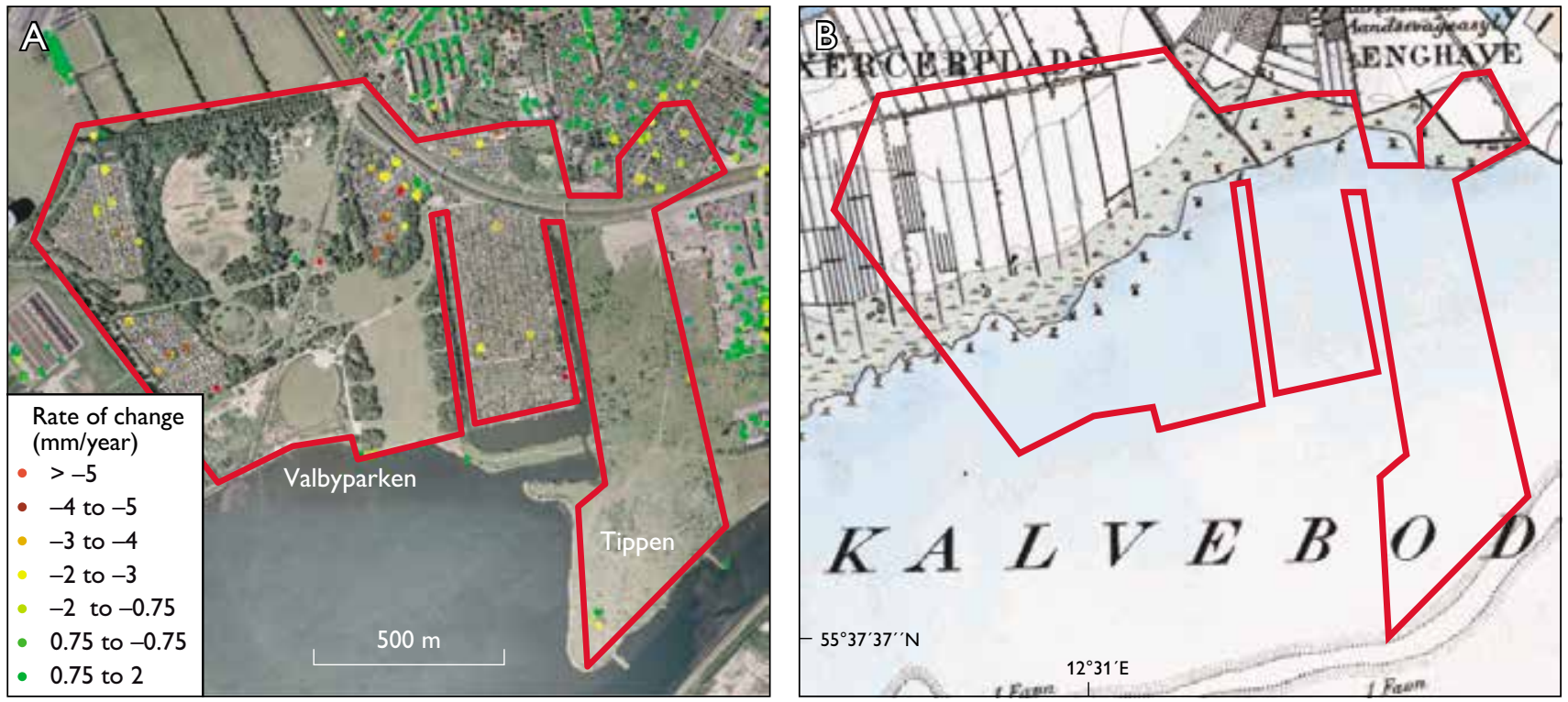

Fig. 4. Detailed map of the Kalveboderne area where waste and fill have been deposited on Holocene marine and coastal deposits. A: Orthophotograph with PSI data points. B: An old topographical map showing the same area prior to deposition of waste and fill. For location see Fig. 2. 


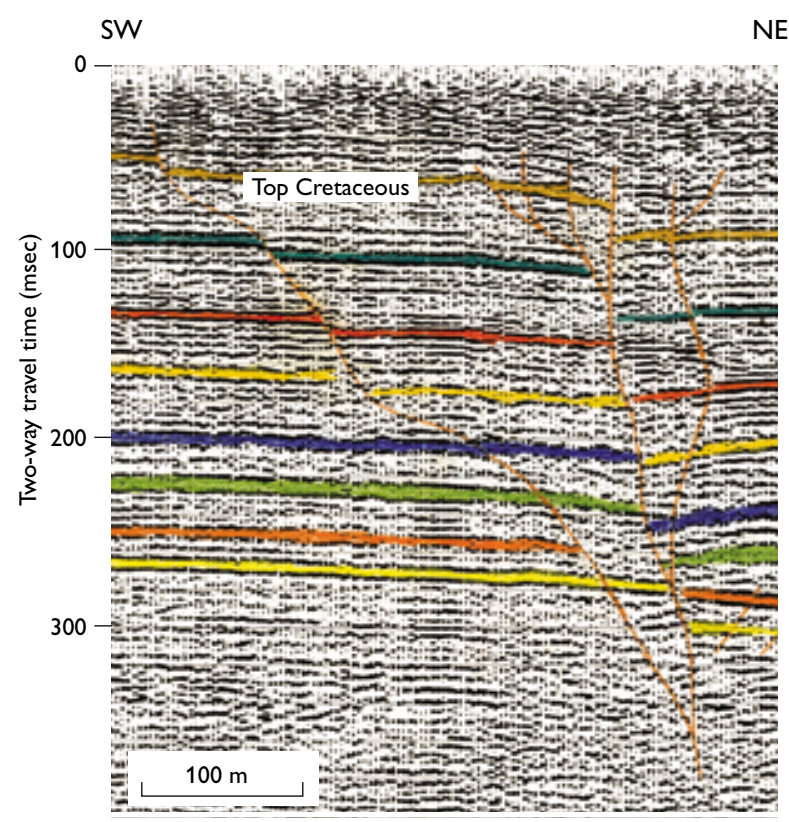

Fig. 5. Seismic cross-section of the Carlsberg fault zone (from Jakobsen $e t$ al. 2002). Maastrichtian chalk is found at the top of the western block, whereas Danian limestone is present at the top of the eastern block.

to the Tornquist-Sorgenfrei wrench fault zone. A seismic cross-section of the Carlsberg fault zone shows that it can be classified as a negative flower structure with a mean vertical offset of 50-100 $\mathrm{m}$ of the limestone deposits. The hanging block is found north-east of the fault zone (Fig. 5; Fallesen 1995; Jakobsen et al. 2002). The limestone in the fault zone itself is strongly fractured as documented by low seismic velocity in the fault-affected zone (Nielsen et al. 2005). There is clear evidence of weak, regional subsidence east of the fault zone, i.e. the area of the down-thrown fault block (Fig. 1). The Carlsberg fault zone can be followed north-westwards to Furesø, which is the deepest lake in Denmark, and we suggest that the shape of the lake is governed by displacement along the fault zone. This would be an alternative explanation of the origin of the lake, which has hitherto been regarded as formed from a combination of tunnel valleys and kettle holes. The subsidence recorded by the PSI points may correspond to subsidence rates in the Copenhagen area recorded from traditional levelling (Mark \& Jensen 1982). Groundwater extraction may also influence subsidence, which could have been the case for Amager. However, the groundwater level on Amager was stable during the period of the satellite data acquisition.

\section{References}

Crosetto, M., Monserrat, O., Adam, N., Parizzi, A., Bremmer, C., Dortland, S., Hanssen, R.F. \& van Leijen, F.J. 2008: Validation of existing processing chains in Terrafirma stage 2, final report, 15 pp., http://www. terrafirma.eu.com/validation/ValProj/Final\%20Reports/ValProj_Final_report.pdf.

Fallesen, J. 1995: Stratigraphy and structure of the Danian Limestone on Amager, examined with geophysical investigations - especially with regard to the Carlsberg Fault. Unpublished MSc thesis, University of Copenhagen, Denmark

Jakobsen, P.R., Fallesen, J. \& Knudsen, C. 2002: Strukturer i den københavnske undergrund - folder, forkastninger og sprækker. Dansk Geoteknisk Forening Bulletin 19, 19-29.

Mark, A. \& Jensen, J.E. 1982: Niveauændringer i København bestemt ud fra gentagne præcisionsnivellementer. Landinspektøren 32, 10-21.

Nielsen, L., Thybo, H. \& Jørgensen, M.I. 2005: Integrated seismic interpretation of the Carlsberg Fault zone, Copenhagen, Denmark. Geophysical Journal International 162, 461-478.

Pedersen, S.A.S., Cooksley, G., Gaset, M. \& Jakobsen, P.R. 2011: Detection of terrain changes in southern Denmark using persistent scatterer interferometry. Geological Survey of Denmark and Greenland Bulletin 23, 41-44.

Rørdam, K. 1899: Beskrivelse til geologisk Kort over Danmark, (i Maalestok 1:100,000). Kortbladene Kjøbenhavn og Roskilde. Danmarks Geologiske Undersøgelse I. Række 6, 88 pp.

Stenestad, E. 1976: Københavnsområdets geologi især baseret på citybaneundersøgelserne. Danmarks Geologiske Undersøgelse III. Række 45, 149 pp. (with summary in English).

Surlyk, F., Damholt, T. \& Bjerager, M. 2006: Stevns Klint: uppermost Maastrichtian chalk, Cretaceous-Tertiary boundary, and lower Danian bryozoan mound complex. Bulletin of the Geological Society of Denmark 54, 1-48.

\footnotetext{
Authors' addresses

P.R.J. \& S.A.S.P, Geological Survey of Denmark and Greenland, Øster Voldgade 10, DK-1350 Copenhagen K, Denmark. E-mail: prj@geus.dk U.W., Gamma Remote Sensing, Worbstrasse 225, CH-3073 Gümligen, Switzerland.

R.C., NPA Satellite Mapping, Crockham Park, Edenbridge, Kent TN8 6SR, UK.
} 